\title{
Hubungan Kebutuhan Pelayanan Keluarga Berencana pada Remaja Belum Kawin dengan Niat Menggunakan Kontrasepsi di Masa Dewasa (Analisis SDKI 2017)
}

\section{Relationship Between Family Planning Service Needs of Unmarried Adolescents and Intention to Use Contraception in The Future (Analysis of IDHS 2017)}

Tiara Adella $^{1 *}$, Rita Damayanti $^{1}$, Martya Rahmaniati Makful $^{2}$

${ }^{1}$ Departemen Pendidikan Kesehatan dan Ilmu Perilaku, Fakultas Kesehatan Masyarakat, Universitas Indonesia, Depok 16424

${ }^{2}$ Departemen Biostatistik dan Kependudukan, Universitas Indonesia, Depok 16424

\author{
*Korespondensi penulis: \\ tiaradella3110@gmail.com
}

\section{ABSTRAK}

Diterima (Recieved)

Direvisi (Revised)

Diterima untuk diterbitkan (Accepted)

\author{
: 19 Agustus 2020 \\ : 11 Oktober 2020 \\ : 5 Februari 2021
}

Latar Belakang. Indonesia adalah negara dengan populasi terbanyak di Asia Tenggara. Dalam mengantisipasi masalah laju pertumbuhan penduduk, Pemerintah mempersiapkan program Keluarga Berencana dan salah satu sasarannya adalah remaja.

Tujuan. Penelitian ini bertujuan untuk mengetahui hubungan antara kebutuhan pelayanan keluarga berencana pada remaja belum kawin dengan niat menggunakan kontrasepsi di masa dewasa

Metode. Penelitian menggunakan kuantitatif analitik dengan pendekatan cross sectional. Kuesioner yang digunakan Remaja Pria (RP) dan Wanita Usia Subur (WUS). Populasi dalam penelitian ini adalah seluruh remaja belum kawin di Indonesia dengan sampel berjumlah 18.464 responden.

Hasil. 82,6\% remaja yang berniat menggunakan kontrasepsi di masa dewasa. Hasil uji chi-square terdapat hubungan antara kebutuhan pelayanan KB pada remaja belum kawin dengan niat menggunakan kontrasepsi di masa dewasa. Hasil analisis multivariat, ada hubungan antara kebutuhan pelayanan KB pada remaja belum kawin dengan niat menggunakan kontrasepsi di masa dewasa setelah di kontrol variabel perancu.

Kesimpulan. Remaja pria belum kawin yang tidak butuh pelayanan KB, terpapar media massa, memiliki pengetahuan $<4$ alat/cara KB lebih tidak berniat menggunakan kontrasepsi di masa dewasa.

Kata Kunci: kebutuhan, keluarga berencana, niat, remaja

\begin{abstract}
Background. Indonesia is the country with the most population in Southeast Asia. In anticipating a Population Growth Rate problem, the government is preparing a family planning program with youth as one of the targets. Objective. This study aimed to determine the relationship between the need for family planning services in unmarried adolescents and the intention to use contraception in adulthood.

Method. The study is quantitative analytic with a cross-sectional approach. The questionnaire used by Adolescent Men (RP) and Women of Fertile Age (WUS). The population in this study were all unmarried adolescents in Indonesia, with sample amount 18,464 respondents.

Results. $82.6 \%$ of adolescents intend to use contraception in the future. Chi-square test results show a relationship between the need for family planning services for unmarried adolescents with the intention to use contraception in adulthood. The result of the multivariate analysis shows a relationship between the need for family planning services for unmarried adolescents with the intention to use contraception in adulthood after being controlled for confounding variables.

Conclusion: Unmarried male adolescents who do not need family planning services, are exposed to mass media, have knowledge of $<4$ methods/methods of contraception and do not intend to use contraception in adulthood.
\end{abstract}

Keywords: adolescent, family planning, intention, needs 


\section{LATAR BELAKANG}

Berdasarkan World Population Prospects (WPP), populasi dunia terus tumbuh dari 7,7 miliar pada tahun 2019 menjadi sekitar 8,5 miliar pada tahun 2030 dan diperkirakan akan mencapai 9,7 miliar pada tahun $2050 .{ }^{1}$ Pertumbuhan populasi yang lebih rendah berarti mengarah pada pendapatan dan investasi yang lebih tinggi. ${ }^{2}$ Sebaliknya, pertumbuhan populasi yang tinggi dapat membuat siklus kemiskinan antar generasi dan kurangnya akses keterampilan, alat, serta peluang yang diperlukan untuk meningkatkan masa depan mereka. ${ }^{3}$ Pada tahun 2019, Asia merupakan wilayah dengan jumlah penduduk terbanyak yaitu 4.6 miliar. ${ }^{1}$ Jumlah penduduk Asia Tenggara diproyeksikan berjumlah 647,45 juta. $^{1}$ Secara global, remaja yang berusia 15-24 tahun seki$\operatorname{tar} 18 \%$ dari seluruh penduduk atau 1,2 miliar. $^{4}$

Dalam mengantisipasi kemungkinan timbulnya masalah Laju Pertumbuhan Penduduk (LPP) pemerintah mempersiapkan program Keluarga Berencana. ${ }^{5}$ Keluarga Berencana bukan hanya kunci memperlambat pertumbuhan populasi, tetapi juga merupakan strategi mengatur tentang kapan ingin mempunyai anak, jarak anak dan perencanaan jumlah kelahiran di masa mendatang. ${ }^{5}$ Dalam program Family Planning 2020 (FP2020) terdapat komitmen bahwa setiap individu, termasuk remaja, mempunyai hak mendapat layanan Keluarga Berencana. ${ }^{3}$

Menurut laporan Survei Dasar Kesehatan Indonesia (SDKI) 2017, terjadi peningkatan proporsi remaja wanita belum kawin yang tidak ingin memakai kontrasepsi di masa mendatang dari $4 \%$ pada 2012 menjadi $7 \%$ pada 2017 , sedangkan persentase remaja pria belum kawin mengalami kenaikan dari $15 \%$ pada 2012 menjadi $20 \%$ pada 2017. ${ }^{6}$ Sejalan dengan studi penelitian Yuni Suryani dan Andrei Ramani, remaja yang tidak ingin mengikuti kontrasepsi di masa depan sebesar 49,6\%. ${ }^{7}$ Hasil temuan Thin Zaw, Liabsuetrakul, Htay, \& McNeil menunjukkan remaja yang belum pernah kawin memiliki pemanfaatan yang rendah terhadap pelayanan Sexual and Reproductive Health (SRH) sehingga tingkat kebutuhan yang belum terpenuhi untuk layanan SRH adalah $67 \%$ termasuk pelayanan keluarga berencana. ${ }^{8}$
Remaja berhak memiliki akses dalam pelayanan KB. ${ }^{3}$ Bentuk pelayanan $\mathrm{KB}$ yang diberikan bagi remaja belum kawin diantaranya informasi, konseling dan penyediaan alat KB. ${ }^{6}$ Menurut laporan SDKI dalam 10 tahun terakhir (2007-2017) remaja belum kawin yang berpendapat bahwa perlunya pelayanan keluarga berencana mengalami penurunan yaitu $90 \%$ menjadi $85 \%$ pada remaja wanita dan $85 \%$ menjadi $81 \%$ pada remaja pria. ${ }^{6}$ Studi di Thailand memperlihatkan bahwa penyedia layanan menyadari anak muda yang belum kawin dihadapkan pada perilaku seksual berisiko namun sebagian besar remaja masih menghadapi berbagai kendala memperoleh informasi dan layanan yang sesuai. ${ }^{9}$

Dari uraian tersebut, menunjukkan perlunya penelitian yang berfokus pada kebutuhan pelayanan keluarga berencana pada remaja belum kawin yang diduga dapat mempengaruhi niat mereka untuk menggunakan kontrasepsi di masa dewasa nanti. Tujuan penelitian ini adalah mengetahui hubungan antara kebutuhan pelayanan keluarga berencana pada remaja belum kawin dengan niat menggunakan kontrasepsi di masa dewasa.

\section{METODE}

Metode dalam penelitian ini adalah kuantitatif analitik korelasi dengan pendekatan cross-sectional. ${ }^{10}$ Populasi dalam penelitian ini adalah remaja pria belum kawin dan remaja wanita belum kawin usia 15-24 tahun di Indonesia. Sampel pada penelitian ini adalah seluruh populasi target yang memenuhi kriteria yaitu pria dan wanita yang berusia 15-24 tahun, belum kawin yang terpilih menjadi sampel penelitian dalam SDKI 2017, mengetahui minimal 1 jenis kontrasepsi dan memiliki data lengkap (tidak missing). Jumlah sampel yang memenuhi kriteria penelitian adalah sebanyak 18.464 responden. Kuesioner yang digunakan Remaja Pria (RP) dan Wanita Usia Subur (WUS). Analisis data meliputi univariat (deskriptif), analisis bivariat (chi-square) dan analisis multivariat (regresi logistik ganda). ${ }^{11}$

Variabel terikat dalam penelitian ini adalah niat menggunakan kontrasepsi di masa dewasa, yaitu keinginan untuk memakai alat/cara $\mathrm{KB}$ di masa mendatang. Adapun variabel bebas dalam penelitian ini adalah kebutuhan 
pelayanan KB pada remaja belum kawin. Bentuk pelayanan KB yang dimaksud adalah informasi, konseling dan penyediaan alat KB. Karakteristik responden dalam penelitian ini mencakup jenis kelamin dan usia. Jenis kelamin adalah perbedaan antara wanita dengan pria secara biologis sejak lahir, sedangkan usia adalah lama waktu hidup responden sejak dilahirkan hingga wawancara dilakukan dalam hitungan tahun. Paparan media massa dalam penelitian ini adalah keterpajanan media massa (televisi, radio, dan media cetak) pesan tentang pencegahan kehamilan selama 6 bulan terakhir. Pengetahuan alat/cara KB dalam penelitian ini adalah pengetahuan wanita dan pria mengenai alat/cara KB terdiri dari MOW, MOP, pil, IUD, suntik KB, implan, kondom, diafragma, MAL, kontrasepsi darurat, pantang berkala, sanggama terputus.

Penelitian ini menggunakan data sekunder lanjutan dari Survei Dasar Kesehatan Indonesia (SDKI) 2017 didapat secara online melalui website resmi DHS (http://dhsprogram.com/). Peneliti sudah mendapat ijin konfirmasi untuk mengambil dan menggunakan data. Kerahasiaan identitas responden dijaga dengan menggunakan kode oleh pemilik data yaitu BPS, BKKBN, dan Kemenkes RI. Surat lolos kaji etik dari Fakultas Kesehatan Masyarakat Universitas Indonesia Nomor: Ket-382/ UN2.F10. D11/PPM.00.02/2020.

\section{HASIL}

Tabel 1 berisi jenis kelamin, umur, kebutuhan pelayanan KB, niat menggunakan kontrasepsi, paparan media massa dan pengetahuan alat/cara KB. Proporsi remaja pria lebih banyak dibanding wanita yaitu pria 53,6\% dan remaja wanita 46,4\%. Usia remaja 15-19 tahun $61,5 \%$ lebih banyak dibanding usia remaja $20-$ 24 tahun $38,5 \%$. Remaja yang butuh pelayanan KB lebih banyak 87,6\% dibandingkan dengan remaja yang tidak butuh pelayanan $\mathrm{KB}$ yaitu $12,4 \%$. Remaja yang berniat menggunakan kontrasepsi di masa dewasa lebih banyak $(82,6 \%)$ dibandingkan dengan remaja yang tidak berniat menggunakan kontrasepsi $(17,4 \%)$. Remaja yang tidak terpapar media massa $(63,2 \%)$ lebih banyak dibanding remaja yang terpapar media massa $(36,8 \%)$. Remaja yang memiliki pengetahuan $\geq 4$ alat/cara $\mathrm{KB}$ $66,9 \%$ lebih banyak dibanding remaja yang memiliki pengetahuan $<4$ alat/cara KB 33,1\%.

Tabel 2 menjelaskan hubungan antara kebutuhan pelayanan KB pada remaja belum kawin dengan niat menggunakan kontrasepsi dimasa dewasa nilai $p$-value $=0,001$. Remaja yang tidak butuh pelayanan KB dan tidak berniat menggunakan kontrasepsi sebanyak $27,1 \%$, sedangkan remaja yang butuh pelayanan KB dan tidak berniat menggunakan kontrasepsi di masa dewasa sebanyak 16,1\%.

Hasil analisis menunjukkan ada hubungan antara jenis kelamin dengan niat menggunakan kontrasepsi di masa dewasa diperoleh nilai $p$ value $=0,001$. Remaja wanita yang tidak berniat menggunakan kontrasepsi sebanyak 7,9\%, sedangkan remaja pria yang tidak berniat menggunakan kontrasepsi di masa dewasa sebanyak $25,7 \%$.

Terdapat hubungan antara usia dengan niat menggunakan kontrasepsi di masa dewasa diperoleh nilai $p$-value $=0,014$. Remaja usia 20-24 tahun yang tidak berniat menggunakan kontrasepsi sebanyak 16,6\%, sedangkan remaja usia 15-19 tahun yang tidak berniat menggunakan kontrasepsi di masa dewasa sebanyak $17,9 \%$.

Tabel 1. Distribusi Responden Menurut Variabel Bebas Pada Remaja Belum Kawin

\begin{tabular}{lcc}
\hline Variabel & n & \% \\
\hline Jenis Kelamin & & \\
Wanita & 8573 & 46.4 \\
Pria & 9892 & 53.6 \\
Umur & & \\
20-24 Tahun & 7102 & 38.5 \\
15-19 Tahun & 11362 & 61.5 \\
Kebutuhan Pelayanan KB & & \\
Butuh & 16184 & 87.6 \\
Tidak & 2280 & 12.4 \\
Niat Menggunakan Kontrasepsi & & \\
Ya & 15247 & 82.6 \\
Tidak & 3217 & 17.4 \\
Paparan Media Massa & & \\
Terpapar & 6801 & 36.8 \\
Tidak & 11664 & 63.2 \\
Pengetahuan alat/cara KB & & \\
Pengetahuan $\geq 4$ alat/cara KB & 12361 & 66.9 \\
Pengetahuan <4 alat/cara KB & 6103 & 33.1 \\
\hline
\end{tabular}


Adella et al. Perilaku dan Promosi Kesehatan: Indonesian Journal of Health Promotion and Behavior. 2021; 3(1): 1-7 DOI: $10.47034 /$ ppk.v3i1.4146

Tabel 2. Distribusi Responden Menurut Variabel Bebas dan Niat Menggunakan Kontrasepsi di Masa Dewasa pada Remaja Belum Kawin

\begin{tabular}{|c|c|c|c|c|c|c|c|c|}
\hline \multirow{3}{*}{ Variabel } & \multicolumn{4}{|c|}{ Niat Menggunakan Kontrasepsi } & \multirow[t]{3}{*}{$\mathbf{O R}$} & \multirow{2}{*}{\multicolumn{2}{|c|}{$\begin{array}{l}\text { 95\% C.I. for } \\
\text { EXP(B) }\end{array}$}} & \multirow[t]{3}{*}{ P Value } \\
\hline & \multicolumn{2}{|c|}{ Ya } & \multicolumn{2}{|c|}{ Tidak* } & & & & \\
\hline & $\mathbf{n}$ & $\%$ & n & $\%$ & & Lower & Upper & \\
\hline \multicolumn{9}{|c|}{ Kebutuhan Pelayanan KB } \\
\hline Butuh & 13586 & 83.9 & 2598 & 16.1 & 1.949 & 1.761 & 2.157 & 0,001 \\
\hline Tidak* & 1661 & 72.9 & 619 & 27.1 & & & & \\
\hline \multicolumn{9}{|l|}{ Jenis Kelamin } \\
\hline Wanita & 7898 & 92.1 & 675 & 7.9 & 4.047 & 3.696 & 4.431 & 0,001 \\
\hline Pria* & 7350 & 74.3 & 2542 & 25.7 & & & & \\
\hline \multicolumn{9}{|l|}{ Usia } \\
\hline 20-24 Tahun & 5920 & 83.4 & 1182 & 16.6 & 1.093 & 1.010 & 1.182 & $0, .014$ \\
\hline 15-19 Tahun* & 9327 & 82.1 & 2035 & 17.9 & & & & \\
\hline \multicolumn{9}{|c|}{ Paparan Media Massa } \\
\hline Terpapar & 5937 & 87.3 & 864 & 12.7 & 1.737 & 1.596 & 1.890 & 0,001 \\
\hline Tidak* & 9311 & 79.8 & 2353 & 20.2 & & & & \\
\hline \multicolumn{9}{|c|}{ Pengetahuan alat/cara KB } \\
\hline Pengetahuan $\geq 4$ & 10604 & 85.8 & 1757 & 14.2 & 1.897 & 1.756 & 2.050 & 0,001 \\
\hline Pengetahuan $<4^{*}$ & 4644 & 76.1 & 1460 & 23.9 & & & & \\
\hline
\end{tabular}

Significant $\mathrm{a} \leq 0.05$
Setelah melakukan analisis, terdapat hubungan antara paparan media massa dengan niat menggunakan kontrasepsi di masa dewasa diperoleh nilai $p$-value $=0,0001$. Remaja terpapar media massa yang tidak berniat menggunakan kontrasepsi sebanyak 12,7\%, sedangkan remaja tidak terpapar media massa yang tidak berniat menggunakan kontrasepsi di masa dewasa sebanyak 20,2\%.

Analisis menunjukkan hubungan antara pengetahuan alat/cara KB dengan niat menggunakan kontrasepsi di masa dewasa dengan diperolehnya nilai $p$-value $=0,001$. Remaja dengan pengetahuan $\geq 4$ alat/cara KB yang tidak berniat menggunakan kontrasepsi sebanyak $14,2 \%$, sedangkan remaja dengan pengetahuan $<4$ alat/cara KB yang tidak berniat menggunakan kontrasepsi di masa dewasa sebanyak $23,9 \%$.

Tabel 3 menjabarkan analisis multivariat menggunakan regresi logistik ganda untuk

mengetahui apakah ada faktor risiko antara variabel utama (kebutuhan pelayanan $\mathrm{KB}$ ) dengan variabel perancu serta menguji apakah variabel tersebut juga merupakan sebagai variabel perancu. Setalah dilakukan uji confounding/perancu dengan melihat perubahan OR > $10 \%$ pada variabel independen yaitu kebutuhan pelayanan keluarga berencana pada remaja belum kawin. Tidak terdapat satupun variabel perancu dalam hubungan kebutuhan pelayanan keluarga berencana pada remaja belum kawin dengan niat menggunakan kontrasepsi di masa dewasa.

Selanjutnya, pada tabel 4 terlihat model akhir multivariat yang menunjukkan kebutuhan pelayanan KB memiliki nilai OR sebesar 2 , artinya remaja yang tidak butuh pelayanan KB memiliki peluang 2 kali untuk tidak berniat menggunakan kontrasepsi di masa mendatang dibanding remaja yang butuh pelayanan $\mathrm{KB}$.

Tabel 3. Perubahan OR pada Variabel Kebutuhan Pelayanan KB

\begin{tabular}{lcccc}
\hline \multicolumn{1}{c}{ Tahap Pemodelan } & OR lama & OR Baru & Perubahan OR & Keterangan \\
\hline Model 1 jenis kelamin & 1.826 & 1.709 & $-6,4$ & Bukan perancu \\
Model 2 pengetahuan alat/cara KB & 1.826 & 1.854 & 1,5 & Bukan perancu \\
Model 3 paparan media massa & 1.826 & 1.970 & 7,8 & Bukan perancu \\
Model 4 Usia & 1.826 & 2.000 & 9,5 & Bukan perancu \\
\hline
\end{tabular}

Tabel 4. Model Akhir Multivariat

\begin{tabular}{lccccc}
\multicolumn{1}{c}{ Variabel } & B & P-value & OR & \multicolumn{2}{c}{ 95\% C.I.for EXP(B) } \\
& & & & Lower & Upper \\
\hline Kebutuhan Pelayanan KB & 0.693 & 0.001 & 2.000 & 1.848 & 2.166 \\
Constant & -0.978 & 0.001 & 0.376 & & \\
\hline Significant $a<0.05$ & & & &
\end{tabular}




\section{PEMBAHASAN}

Menurut Theory of Planned Behavior ${ }^{12}$, niat dipengaruhi sikap terhadap perilaku, norma subjektif dan kontrol perilaku. Niat (Intention) merupakan kemampuan diri individu yang didasarkan pada keinginan melakukan perilaku tertentu. ${ }^{12}$ Hasil penelitian ini menunjukkan proporsi remaja yang berniat menggunakan kontrasepsi di masa dewasa lebih banyak dibanding remaja yang tidak berniat menggunakan kontrasepsi. Sejalan dengan penelitian Fajriyah ${ }^{13}$ menyebutkan lebih banyak proporsi remaja yang ingin menggunakan kontrasepsi di masa dewasa dibanding remaja yang tidak ingin menggunakan kontrasepsi.

Dalam penelitian ini pelayanan KB diartikan sebagai faktor yang mendasari niat untuk menggunakan kontrasepsi di masa dewasa, sehingga remaja berpikir bahwa pelayanan keluarga berencana sebagai kebutuhannya. ${ }^{6,12}$ Pelayanan KB yang dimaksud adalah informasi, konseling dan penyediaan alat KB. ${ }^{6}$ Ada hubungan antara kebutuhan pelayanan keluarga berencana pada remaja belum kawin dengan niat menggunakan kontrasepsi di masa dewasa. Remaja yang tidak butuh pelayanan KB dan tidak berniat menggunakan kontrasepsi lebih banyak dibanding remaja yang butuh pelayanan KB dan tidak berniat menggunakan kontrasepsi di masa dewasa. Hal ini sejalan penelitian Thin Zaw et $\mathrm{al}^{8}$ dengan hasil remaja belum kawin memiliki pemanfaatan yang rendah terhadap pelayanan Sexual and Reproductive Health (SRH) sehingga tingkat kebutuhan yang belum terpenuhi untuk layanan SRH termasuk Keluarga Berencana.

Hasil penelitian ini menunjukkan proporsi remaja pria lebih banyak dibanding wanita. Ada hubungan antara jenis kelamin dengan niat menggunakan kontrasepsi di masa dewasa. Remaja pria lebih banyak tidak berniat menggunakan kontrasepsi dimasa dewasa dibanding remaja wanita. Hal ini sejalan dengan penelitian yang dilakukan oleh Yuni Suryani, Andrei Ramani ${ }^{7}$ yang mengatakan bahwa remaja wanita lebih cenderung akan menggunakan $\mathrm{KB}$ di masa depan dibandingkan remaja pria. Lingkungan sosial budaya menganggap bahwa keluarga berencana dan kesehatan reproduksi merupakan urusan wanita. ${ }^{14}$ Terbatasnya alat kontrasepsi, informasi, aksesibilitas pelayanan keluarga berencana dan kesehatan reproduksi bagi pria, sehingga remaja pria memiliki partisipasi rendah dalam keluarga berencana. ${ }^{14}$

Sebuah studi baru Susan Sawyer di Lancet Child \& Adolescent Health ${ }^{15}$, menyebutkan rentang usia baru untuk masa remaja menuju dewasa yaitu usia 10-24 tahun sesuai dengan pertumbuhan remaja. Masa pubertas dimulai pada usia 10 dan fase di mana orang muda menjadi dewasa dan memiliki peran serta tanggung jawab orang dewasa adalah dimulai pada usia 24 tahun seperti menunda masa transisi peran, termasuk penyelesaian pendidikan, pernikahan, dan menjadi orang tua. Perpanjangan masa transisi antara masa kanak-kanak sampai dewasa dikaitkan dengan banyak faktor, termasuk perubahan sosial dan biologis. Media digital dan kemajuan teknologi juga menjadi faktor pendukung. ${ }^{15}$

Di Indonesia, usia 15-24 tahun termasuk dalam kategori remaja. Hasil penelitian memperlihatkan ada hubungan antara usia dengan niat menggunakan kontrasepsi di masa dewasa. Remaja usia 15-19 tahun yang tidak berniat menggunakan kontrasepsi dimasa dewasa lebih banyak dibanding remaja usia 20-24 tahun. Sejalan penelitian Fajriyah ${ }^{13}$ dengan hasil remaja usia 20-24 tahun cenderung lebih menginginkan menggunakan kontrasepsi dibanding remaja usia 15-19 tahun. Semakin bertambahnya umur maka tingkat kematangan berpikir dan bekerja seseorang akan lebih matang. ${ }^{15}$

Hasil penelitian menunjukkan remaja yang terpapar media massa lebih banyak dibanding remaja yang tidak terpapar media massa. Ada hubungan antara paparan media massa dengan niat menggunakan kontrasepsi di masa dewasa. Remaja yang tidak terpapar media massa dan tidak berniat menggunakan kontrasepsi di masa dewasa lebih banyak dibanding remaja yang terpapar media massa. Sejalan dengan penelitian Appiah et $\mathrm{al}^{13}$, responden yang membaca koran dan menonton TV lebih mungkin menggunakan kontrasepsi dibandingkan dengan remaja yang tidak membaca koran dan menonton TV sama sekali. Didukung studi penelitian Char, Saavala, \& 
Kulmala $^{18}$, temuan ini juga menunjukkan perlunya mengembangkan strategi yang efektif mendidik remaja serta meningkatkan akses mereka ke informasi dan layanan KB sehingga dapat mengurangi IMS dan risiko kehamilan yang tidak diinginkan. Responden juga menyebutkan bahwa pentingnya media massa dalam hal mengakses keluarga berencana. ${ }^{18}$

Pengetahuan alat/cara KB merupakan hal yang penting dimiliki sebagai bahan pertimbangan sebelum menggunakannya. Sebagian besar pengetahuan manusia diperoleh melalui mata dan telinga. ${ }^{19}$ Ada hubungan antara pengetahuan alat/cara KB dengan niat menggunakan kontrasepsi di masa dewasa. Remaja dengan pengetahuan $<4$ alat/cara KB yang tidak berniat menggunakan kontrasepsi lebih banyak dibanding remaja dengan pengetahuan $\geq 4$ alat/cara KB. Hal ini sejalan dengan penelitian Yuni Suryani dan Andrei Ramani ${ }^{7}$, remaja yang mempunyai pengetahuan tentang $\mathrm{KB}$ dalam kategori tinggi memiliki kecenderungan 23,5 kali lebih mungkin untuk mengikuti KB apabila sudah menikah untuk mengatur kehamilan daripada remaja yang mempunyai pengetahuan rendah tentang KB. Semakin banyak informasi yang diterima maka semakin tinggi pula pengetahuan terkait KB. ${ }^{7}$

\section{KESIMPULAN}

Remaja pria belum kawin yang tidak butuh pelayanan $\mathrm{KB}$, usia 15-19 tahun, terpapar media massa, memiliki pengetahuan <4 alat/cara KB lebih tidak berniat menggunakan kontrasepsi di masa dewasa. Ada hubungan antara kebutuhan pelayanan keluarga berencana pada remaja belum kawin dengan niat menggunakan kontrasepsi di masa dewasa setelah di kontrol variabel perancu jenis kelamin, usia, paparan media massa dan pengetahuan alat/cara.

\section{SARAN}

Diperlukan kerjasama antara bidang keilmuan dan BKKBN dalam membuat strategi Promosi Kesehatan tentang pelayanan KB yang sesuai dengan kebutuhan remaja belum kawin. Meningkatkan pemberian informasi tentang pendewasaan usia perkawinan pada remaja melalui kegiatan yang berbasis masyarakat seperti karang taruna. Diharapkan peneliti selanjutnya dapat meneliti dengan menggunakan lebih banyak variabel dengan desain penelitan yang berbeda, serta menggunakan data primer.

\section{UCAPAN TERIMA KASIH}

Penulis mengucapkan terima kasih sebesarbesarnya kepada pihak-pihak yang telah membantu dalam penelitian ini sehingga artikel ini dapat terbit

\section{DAFTAR REFERENSI}

1. Nations U. World population prospects 2019 [Internet]. Department of Economic and Social Affairs. World Population Prospects 2019. 2019. Available from: http://www.ncbi.nlm.nih.gov/pubmed/12283 219

2. J. Dodson, "Masa Depan Indonesia Bergantung pada Keluarga Berencana," 12 mei 2019. [Online]. Available: https://www.matamatapolitik.com/opinimasa-depan-indonesia-bergantung-padakeluarga-berencana/

3. WHO, Achieving universal health coverage for the world's 1.2 billion adolescents, 2018.

4. BPS. Statistik Pemuda Indoneisa. 2019.

5. BKKBN. Rencana Strategis Badan Kependudukan Dan Keluarga Berencana Nasional Tahun 2015-2019 [Internet]. Badan Kependudukan dan Keluarga Berencana Nasional. 2015. 1-43 p. Available from: https://www.bkkbn.go.id/pocontent/uploads/RENSTRA_BKKBN\%2520 2015-2019.pdf

6. SDKI [Internet]. Riset Kesehatan Dasar 2018. 2017. 1-446 p. Available https://doi.org/1 Desember 2018

7. Yuni Suryani, Andrei Ramani DMW. Preferensi Remaja dalam Mengikuti Keluarga Berencana di Masa Depan ( Studi Pada Remaja di Kecamatan Kaliwates Kabupaten Jember ) Preferences Of Adolescent In Family Planning In The Future. Artikel Ilmiah Hasil Penelitian Mahasiswa 2015 [Internet]. 2015;1-8. Available from: https://repository.unej.ac.id/bitstream/handle/ 123456789/75424/Yuni

Suryani.pdf?sequence $=1$

8. Thin Zaw PP, Liabsuetrakul T, Htay TT, McNeil E. Equity of access to reproductive health services among youths in resourcelimited suburban communities of Mandalay City, Myanmar. BMC Health Services Research [Internet]. 2012;12(1):1-12. 
Available from:
https://pubmed.ncbi.nlm.nih.gov/23241510/

9. Tangmunkongvorakul, A., Banwell, C., Carmichael, G., Utomo, I. D., Seubsman, S. ang, Kelly, M., \& Sleigh, A. (2012). Use and perceptions of sexual and reproductive health services among Northern Thai adolescents.

Southeast Asian Journal of Tropical

Medicine and Public Health, 43(2), 479-500.

Retrieved from

https://www.ncbi.nlm.nih.gov/pmc/articles/P MC3732782/

10. Notoatmodjo. (2012). Metodologi Penelitian Kesehatan. Jakarta: Rineka Cipta

11. Sugiyono. (2018). Metode Penelitian Kuantitatif, Kualitatif, dan R\&D. Bandung: Alfabeta

12. Icek Ajzen. (2005). Atttudes, Personality and Behavior. International Journal of Strategic Innovative Marketing, Vol. 3, p. 117.

Retrieved from https://psicoexperimental.files.wordpress.co $\mathrm{m} / 2011 / 03 /$ ajzeni-2005-attitudes-personalityand-behavior-2nd-ed-open-universitypress.pdf

13. Fajriyah. (2017). keinginan menggunakan metode kontrasepsi pada remaja di masa mendatang di provinsi jawa timur. Journal of Chemical Information and Modeling, 53(9), 1689-1699.
https://doi.org/10.1017/CBO9781107415324. 004

14. Barus, E., Lumbantoruan, M., \& Purba, A. (2018). Hubungan pengetahuan, sikap dan pelayanan KB dengan keikutsertaan pria mengikuti KB. Journal of Health Studies, 2(2), 33-42.

https://doi.org/10.31101/jhes.451

15. Sawyer, S. M., Azzopardi, P. S.,

Wickremarathne, D., \& Patton, G. C. (2018). The age of adolescence. The Lancet. Child \& adolescent health, 2(3), 223-228.

https://doi.org/10.1016/S2352$4642(18) 30022-1$

16. Suryabudhi. (2003). Perkembangan Bayi dan Anak. Bandung: Pioner jaya.

17. Appiah, F., Seidu, A. A., Ahinkorah, B. O., Baatiema, L., \& Ameyaw, E. K. (2020).

Trends and determinants of contraceptive use among female adolescents in Ghana:

Analysis of 2003-2014 Demographic and Health Surveys. SSM - Population Health, 10, 100554. https://doi.org/10.1016/j.ssmph.2020.100554

18. Char, A., Saavala, M., \& Kulmala, T. (2011). Assessing young unmarried men's access to reproductive health information and services in rural India. BMC Public Health, 11, 1-10. https://doi.org/10.1186/1471-2458-11-476

19. Notoatmodjo, Promosi Kesehatan dan Ilmu Perilaku, Jakarta: Rineka Cipta, 2010 